\title{
Risk Factor Analysis of Community Behavior in the Eradication of Mosquito Nests in Urban and Rural
} Areas

\author{
Kholis Ernawati $^{1 *}$, Nurmaya ${ }^{2}$, Riselligia Caninsti ${ }^{3}$, Yusnita $^{1}$, Dini Widianti ${ }^{1}$, Fikri \\ Satria Kamal ${ }^{1}$, Putri Pasya Permana ${ }^{1}$ Rizka Fadhilah Azmi ${ }^{1}$, Saphira Delinda Kirana ${ }^{1}$ \\ ${ }^{1}$ Faculty of Medicine, YARSI University, 10510, Jakarta, Indonesia \\ ${ }^{2}$ Informatics Engineering Faculty, YARSI University, 10510, Jakarta, Indonesia \\ ${ }^{3}$ Faculty of Psychology, YARSI University, 10510, Jakarta, Indonesia \\ "Corresponding author.Email: kholisernawati@yahoo.co.id
}

\begin{abstract}
Increased DHF cases related to environmental sanitation, including the availability of breeding places for Aedes mosquitoes. Mosquito breeding places are formed because of low public awareness in eradicating Aedes mosquito nests. The objective of this study is to analyze the influence of knowledge, attitudes, availability of material and tools and sources of information on people's behavior in eradicating mosquito nests (PSN). Cross sectional research design and Structural Equation Modeling (SEM) analysis method approach are used in this study. The urban observation unit is the Kemayoran sub-district, Central Jakarta City and the rural area is the Kresek sub-district, Tangerang Regency. The study was conducted in July 2018 March 2019. The number of respondents in each observation unit location was 100 respondents aged $\geq 17$ years. Sampling was collected by incidental sampling. The analysis shows that a) increased knowledge can improve PSN behavior in Kresek $(\mathrm{t}$-value $=4.68), \mathrm{b})$ respondent's attitude has no effect on PSN behavior both in Kemayoran and Kresek, c) availability of tools can improve PSN behavior in Kemayoran ( t-value $=2.31$ ), and d) the source of information has a negative effect on PSN behavior in Kresek (t-value = -3.32).
\end{abstract}

Keywords: Dengue Hemorrhagic Fever, urban, rural, mosquito nest eradication behavior (PSN)

\section{INTRODUCTION}

Dengue Hemorrhagic Fever (DHF) is transmitted by mosquitoes, especially Aedes aegypti, as a vector of the disease transmitters. The Aedes aegypti mosquito is widespread in tropical and subtropical regions and lives and breeds around the house [1].

An increase in dengue cases every year in several regions in Indonesia according to some research is related to environmental sanitation with the availability of breeding sites for mosquitoes. Breeding sites are formed because of the low level of knowledge and low awareness of the community making the efforts to prevent DHF [2]. The strategy in handling DHF is by breaking the chain of Aedes aegypti mosquitoes. It is carried out through epidemiological observation, vector observation and eradication, and eradication of mosquito larvae DBD [3]. Knowledge is one of the predisposing factors of human behavior. Public knowledge influences changes in people's behavior. Knowledge is influenced by several factors such as education, information exposure, occupation, socioculture, economy, environment, experience and age [3].

The handling and controlling of DHF in rural areas will certainly be different from handling it in urban areas based on the risk factors. The results of research in Vietnam and Cambodia informed that cases of dengue fever in rural areas are higher than urban areas [4][5]. A study in the Banjarnegara, Central Java showed that the Aedes aegypti infection rate in urban areas is $11.9 \%$, Aedes albopictus infection rate in rural areas is $17.4 \%$ [6].

The number of DHF cases fluctuate every year. Data from the Directorate of Prevention and Control of Vector and Zoonotic Infectious Diseases of the Indonesian Ministry of Health in 2014, there are about 100,347 people suffers from DHF which 907 of whom died. In 2015, there were 129,650 cases with 1,071 deaths. Whereas in 2016 there were 202,314 cases with 1,593 deaths. In 2017, from January to May there were 17,877 cases with 115 deaths. The morbidity or Incidence Rate (IR) in 34 provinces in 2015 reached 50.75 per 100 thousand population, and IR in 2016 reached 78.85 per 100 thousand population. This figure is still higher than the national IR target of 49 per 100 thousand inhabitants [7].

The key factor of the DHF environment management is the community itself. The community must be actively involved in breaking the chain of dengue infection by managing the environment where mosquitoes breed. Based on the explanation that has been stated, the objective of this 
study is to determine risk factors of the community behavior in eradicating mosquito nests (PSN) in urban and rural areas.

\section{METHOD}

This study used cross sectional research design and Structural Equation Modeling (SEM) analysis method approach. The urban observation area is the Serdang villages, Kemayoran sub-district, Central Jakarta City and for the rural area is the Koper villages, Kresek sub-district, Tangerang Regency. This study was conducted in July 2018 - March 2019.

Data analysis method used in this study is the SEM method. The SEM analysis used in analyzing the research model is expected to identify the dimensions of a construct and at the same time will measure the effect or degree of relationship between the factors that have been identified as dimensions [8]. Another advantage of using SEM is its ability to confirm the dimensions of a concept or factor and its ability to measure the effect of relationships theoretically.

Research variables include endogenous variables (3M behavior and plus the behavior other than $3 \mathrm{M}$ ), exogenous: a) respodent characteristics (education, activities in the environment and income), b) knowledge (mosquito breeding sites and larvae eradication), c) attitudes (3M attitudes and attitude other than $3 \mathrm{M}$ ), d) tools (larvae checker, PSN tools, 3M plus tools) and e) sources of information from health workers (in primary government services, private primary services, and secondary / tertiary services).

According to Hair et al the determination of the minimum sample size for SEM depends on the number of indicators that are presents and multiplied by five to ten [8]. The number of indicator variables in the study is 14 . So the minimum number of samples is 14 x $5=70$ respondents. The number of respondents in the study for each location was 100 respondents aged $\geq 17$ years. So the total number of respondents is 200 people. Sampling was collected by using incidental sampling.

The stages in SEM method analysis are a) development of theoretical models, b) development of flowcharts, c) conversion of flowcharts into a series of structural equations and measurement model specifications, d) selection of input matrices and estimation techniques, e) assessing problems identification and evaluation of goodness of fit criteria.

This research model is built based on the behavioral theory of Lawrence green [9]. Behavior is influenced by predisposing, enabling and reinforcing factors. In this study, community PSN behavior is thought to be influenced by predisposing factors (ie knowledge and attitudes), enabling factors (ie availability of tools and materials), and reinforcing factors (counseling by health workers as a source of information). Path diagrams (Figure 1) are developed based on research models and show causality relationships.

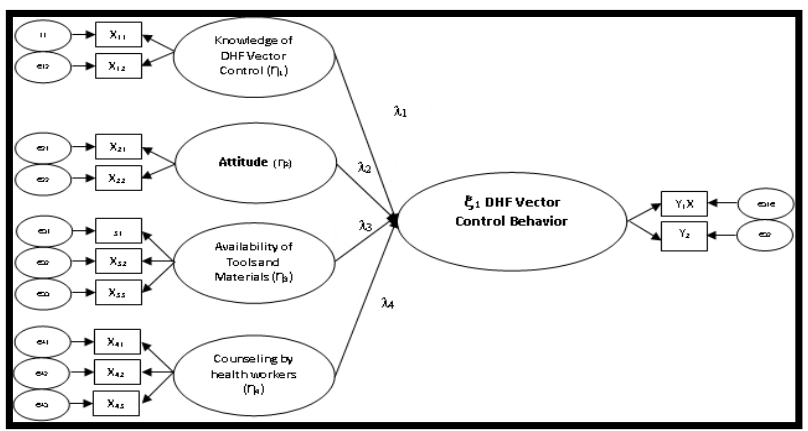

Figure 1. Complete Measurement Model (Path Diagram)

In the research model (Figure 2) it can be seen that the endogenous variable is the DHF vector control behavior. While exogenous variables are knowledge, attitudes, availability of materials, and counseling by health workers. The variable of DHF vector control behavior consists of $3 \mathrm{M}$ behavior and $3 \mathrm{M}$ plus behavior (other than $3 \mathrm{M}$ ). Knowledge variable consists of knowledge of dengue mosquito breeding places and knowledge of mosquito larvae eradication. Attitude variables consist of attitudes about $3 \mathrm{M}$ and $3 \mathrm{M}$ Plus attitudes (other than $3 \mathrm{M}$ ). Variable availability of tools and materials consists of tools for larval inspection, tools for managing vector breeding sites and tools for $3 \mathrm{M}$ Plus. The variable counseling health workers consists of counseling variables by health workers of primary government services, secondary / tertiary services, and private health workers.

Lisrel 8.7 software is used to help the SEM method analysis. To see each indicator of the latent variable tested, it all depends on the t-value and standardized loading factor (SLF). The t-value indicator meets the assumptions if $\geq$ 1.96 and the standardized loading factor (SLF) of the variable is valid or qualified because the SLF value is $\geq$ 0.30 .

\section{RESULTS AND DISCUSSION}

\section{Results}

Respondent characteristics in this study (table 1) showed that the majority were in the age range of 31 - 50 years, both respondents from the Kemayoran area $(63 \%)$ and from the Kresek area $(51 \%)$. The last education level of respondents was high school graduates from both the Kemayoran area (55\%) and the Kresek area (44\%). Respondents' income is mostly less than or equal to the Regional Minimum Wage (UMR) in both the Kemayoran area and the Kresek area

Table 1. Characteristics of Respondents

\begin{tabular}{ccccc}
\hline \multirow{2}{*}{ Variable } & \multicolumn{2}{c}{ Kemayoran } & \multicolumn{2}{c}{ Kresek } \\
\cline { 2 - 5 } & Frequency & Percentage & Frequency & Percentage \\
\hline & \multicolumn{4}{c}{ Age } \\
<30 years & 11 & $11,00 \%$ & 24 & $24,000 \%$ \\
$31-50$ years & 63 & $63,00 \%$ & 51 & $51,00 \%$ \\
$>50$ years & 26 & $26,00 \%$ & 25 & $25,00 \%$ \\
\hline
\end{tabular}




\begin{tabular}{|c|c|c|c|c|}
\hline \multirow{2}{*}{ Variable } & \multicolumn{2}{|c|}{ Kemayoran } & \multicolumn{2}{|c|}{ Kresek } \\
\hline & Frequency & Percentage & Frequency & Percentage \\
\hline Agree & 78 & $78 \%$ & 52 & $52 \%$ \\
\hline \multicolumn{5}{|c|}{ Tool for Monitoring Larvae } \\
\hline $\begin{array}{c}\text { Do not } \\
\text { have }\end{array}$ & 9 & $9 \%$ & 7 & $7 \%$ \\
\hline Have & 91 & $91 \%$ & 93 & $93 \%$ \\
\hline \multicolumn{5}{|c|}{ Tool for controlling DHF Vectors } \\
\hline $\begin{array}{c}\text { Do not } \\
\text { have }\end{array}$ & 22 & $22 \%$ & 37 & $37 \%$ \\
\hline Have & 78 & $78 \%$ & 63 & $63 \%$ \\
\hline \multicolumn{5}{|c|}{ Tool for 3M Plus } \\
\hline $\begin{array}{l}\text { Do not } \\
\text { have }\end{array}$ & 32 & $32 \%$ & 33 & $33 \%$ \\
\hline Have & 68 & $68 \%$ & 67 & $67 \%$ \\
\hline \multicolumn{5}{|c|}{ Counseling From Primary Health Care Workers } \\
\hline $\begin{array}{l}\text { Ever } \\
\text { heard }\end{array}$ & 30 & $30 \%$ & 36 & $36 \%$ \\
\hline $\begin{array}{c}\text { Never } \\
\text { heard of }\end{array}$ & 70 & $70 \%$ & 64 & $64 \%$ \\
\hline \multicolumn{5}{|c|}{ Counseling From Tertiary / Secondary Health Care Workers } \\
\hline $\begin{array}{l}\text { Ever } \\
\text { heard }\end{array}$ & 36 & $36 \%$ & 36 & $36 \%$ \\
\hline $\begin{array}{c}\text { Never } \\
\text { heard of }\end{array}$ & 64 & $64 \%$ & 64 & $64 \%$ \\
\hline \multicolumn{5}{|c|}{ Counseling From Private Service Health Workers } \\
\hline $\begin{array}{l}\text { Ever } \\
\text { heard }\end{array}$ & 37 & $37 \%$ & 48 & $48 \%$ \\
\hline $\begin{array}{l}\text { Never } \\
\text { heard of }\end{array}$ & 63 & $63 \%$ & 52 & $52 \%$ \\
\hline
\end{tabular}

The frequency distribution of all study variables (Table 2) shows that most are positive or as expected. Both on endogenous variables (ie DHF vector control behavior) as well as on exogenous variable variables (ie knowledge, attitudes, availability of materials, and counseling by health workers).

Table 2. Frequency Distribution of Research Model Variables

\begin{tabular}{ccccc}
\hline \multirow{2}{*}{ Variable } & \multicolumn{2}{c}{ Kemayoran } & \multicolumn{2}{c}{ Kresek } \\
\cline { 2 - 5 } & Frequency & Percentage & Frequency & Percentage \\
\hline \multirow{3}{*}{ 3M Behavior } \\
Do not do & 12 & $12 \%$ & 15 & $15 \%$ \\
To do & 88 & $88 \%$ & 85 & $85 \%$ \\
\hline
\end{tabular}

\begin{tabular}{ccccc}
\hline \multicolumn{5}{c}{ 3M Plus Behavior (other than 3M) } \\
Do not do & 30 & $30 \%$ & 44 & $44 \%$ \\
To do & 70 & $70 \%$ & 56 & $56 \%$ \\
\hline \multirow{4}{*}{$\begin{array}{c}\text { DHF Vector } \\
\text { know }\end{array}$} & 19 & $19 \%$ & 24 & $24 \%$ \\
Knowing & 81 & $81 \%$ & 76 & $76 \%$ \\
\hline
\end{tabular}

\begin{tabular}{ccccc}
\hline \multicolumn{5}{c}{ Knowledge of Eradicating Larvae } \\
$\begin{array}{c}\text { Do not } \\
\text { know } \\
\text { Knowing }\end{array}$ & 21 & $21 \%$ & 23 & $23 \%$ \\
\hline \multirow{5}{*}{ Bisagree } & 24 & $79 \%$ & 77 & $77 \%$ \\
Agree & 76 & $76 \%$ & 71 & $71 \%$ \\
\hline & $3 \mathbf{M}$ Plus Attitude (other than 3M) \\
Disagree & 22 & $22 \%$ & 48 & $48 \%$
\end{tabular}

The Model Analysis of Measuring Latent Variables Behavior and Knowledge

Measurement model of latent variables of behavior and knowledge with a comparison of two data namely Kemayoran and Kresek area (Table 3) shows that the value of The Root Mean Square Error of Approximation (RMSEA) of the measurement model in the Kemayoran data is $0,000 \leq 0.08$ which indicates that the overall model fit or the data and model match is close fit. However, the RMSEA value has not been reached for the Kresek data. The T-value for all indicators has met the assumptions requirement, that is $\geq 1.96$ and the standardized loading factor (SLF) of the statement item is valid or qualified for the requirement because the SLF value is $\geq 0.30$. Thus it can be concluded in general that the overall fit of the model for the measurement models of behavior and knowledge variables is good, as well as their validity and reliability. 
the model. Thus it can be concluded in general that the overall fit of the model for the measurement models of behavior and knowledge variables is good, as well as their validity and reliability.

Table 4. Summary of Attitude Measurement Models, Tools, and Information

\begin{tabular}{|c|c|c|c|c|c|c|}
\hline \multirow[b]{2}{*}{ Model } & \multicolumn{3}{|c|}{ Kemayoran n = 100 } & \multicolumn{3}{|c|}{ Kresek n = 100 } \\
\hline & $\begin{array}{l}\text { Loading } \\
\text { Factor }\end{array}$ & $\begin{array}{l}\text { t- } \\
\text { Valu } \\
\text { e }\end{array}$ & $\begin{array}{l}\text { Explana } \\
\text { tion }\end{array}$ & $\begin{array}{l}\text { Loading } \\
\text { Factor }\end{array}$ & t-Value & $\begin{array}{l}\text { explan } \\
\text { ation }\end{array}$ \\
\hline $\begin{array}{l}\text { Behavi } \\
\text { or }\end{array}$ & 1.00 & $\begin{array}{l}14.3 \\
1\end{array}$ & Valid & 1.00 & 14.09 & Valid \\
\hline $\begin{array}{l}\text { Behavi } \\
\text { or }\end{array}$ & 0.87 & $\begin{array}{l}10.9 \\
6\end{array}$ & Valid & 0.72 & 8.41 & Valid \\
\hline Tool-1 & 0.17 & 1.21 & Invalid & 1.00 & 14.07 & Valid \\
\hline Tool-2 & -0.61 & - & Valid & -0.18 & -1.83 & Invalid \\
\hline Tool-3 & -0.50 & - & Valid & 0.13 & 1.35 & Invalid \\
\hline $\begin{array}{l}\text { Counse } \\
\text { ling-1 }\end{array}$ & -0.20 & - & Invalid & -0.31 & 3.11 & Valid \\
\hline $\begin{array}{l}\text { Counse } \\
\text { ling-2 }\end{array}$ & 0.77 & 5.04 & Valid & 1.00 & 14.07 & Valid \\
\hline $\begin{array}{l}\text { Counse } \\
\text { ling-3 }\end{array}$ & 0.59 & 4.41 & Valid & 0.19 & 2.26 & Valid \\
\hline \multicolumn{7}{|c|}{$\begin{array}{l}(\text { Kemayoran }) \text { Chi-Square }=26.75, \mathrm{df}=16, \mathrm{p} \text {-value }=0.04437, \mathrm{RMSEA}= \\
0.082 \\
(\text { Kresek }) \text { Chi-Square }=36.36, \mathrm{df}=16, \mathrm{p} \text {-value }=0.00258, \mathrm{RMSEA}= \\
0.113\end{array}$} \\
\hline
\end{tabular}
model match is close fit. However, the RMSEA value has not been reached for the Kresek Data. The T-value for all indicators meets the assumptions requirement, that is $\geq 1.96$ and the standardized loading factor (SLF) of the statement item is valid except for the indicators Availability of tools and material, and information for Kemayoran data, and availability of tools and material and H-Tools for Kresek data. Invalid data will be considered to be removed from

\section{Structural Model}

After determining the validity and reliability of the measurement model, the next step is to analyze the goodness of fit criteria of the structural model. The results of the conclusion of goodness of fit for both models can be seen in the following table:

Table 5. Structural Model Goodness of Fit Indices (GOFI)

\begin{tabular}{llllll}
\hline \multirow{2}{*}{ GOFI } & Cut-Off Value & Kemayoran & & Kresek & \\
\cline { 3 - 6 } & & Model Result & Remarks & Model Result & Remarks \\
\hline p-value & p-value $\geq 0.05$ & 0.04572 & Marginal Fit & 0.00030 & Marginal Fit \\
RMSEA & RMSEA $\leq 0.08$ & 0.073 & Good Fit & 0.11 & Marginal Fit \\
NFI & NFI $\geq 0.90$ & 0.87 & Marginal Fit & 0.88 & Marginal Fit \\
NNFI & NNFI $\geq 0.90$ & 0.88 & Marginal Fit & 0.85 & Marginal Fit \\
CFI & CFI $\geq 0.90$ & 0.93 & Good Fit & 0.92 & Good Fit \\
IFI & IFI $\geq 0.90$ & 0.94 & Good Fit & 0.92 & Good Fit \\
Standardized & Standardized RMR & 0.091 & & & Marginal Fit \\
RMR & $\leq 0.05$ & 0.93 & Marginal Fit & 0.11 & Good Fit \\
GFI & GFI $\geq 0.90$ & Good Fit & 0.90 & \\
\hline
\end{tabular}

Information:

RMSEA: Root Mean Square Error of Approximation

NFI: Normed Fit Index

NNFI: Non-Normed Fit Index
CFI: Comparative Fit Index

IFI: Incremental Fit Index

RMR: Root Mean Square Residual 
GFI: Goodness of Fit Index (GFI)

Based on table 5, it can be seen that the structural model in the Kemayoran model has several goodness of fit criteria that are considered good fit, including RMSEA, CFI, IFI, and GFI. While other criteria such as p-value, NFI, NNFI, and standardized RMR show marginal fit criteria. While in the Kresek model, there are also several criteria for goodness of fit that are considered good fit, including CFI, IFI, and GFI. While other criteria such as RMSEA, pvalue, NFI, NNFI, and standardized RMR indicate marginal fit criteria. The coefficient test of determination of the two models above can be seen in the following equation:

\section{Kemayoran}

Behavior $=0.31 *$ Knowledge $-0.061 *$ Attitude $+0.73 *$

Tools $-0.17 *$ Counseling, Errorvar $=0.31, \mathrm{R} 2=0.69$

Kresek

Behavior $=1.11 *$ Knowledge $-0.17 *$ Attitude $+0.23 *$

Tool $-0.87 *$ Counseling, $\mathrm{R}^{2}=1.00$

Based on the above equation model, it can be concluded that, the ability of the variable knowledge, attitudes, tools and information in explaining behavior is 0.69 for Kemayoran data and 1.00 for Kresek data, while the rest is explained from variables outside the model. The next step is to explain the results of the hypothesis test with the significance value used is $5 \%$. The condition for accepting the hypothesis is by referring to the t-value in the structural model $\geq 1.96$

Table 6. Hypotheses Testing

\begin{tabular}{|c|c|c|c|c|c|c|c|}
\hline Variables & & Kemayoran & & & Kresek & & \\
\hline $\begin{array}{l}\text { Independent } \\
\text { Variables }\end{array}$ & $\begin{array}{l}\text { Dependent } \\
\text { Variables }\end{array}$ & $\begin{array}{l}\text { Standardized } \\
\text { Solution }\end{array}$ & $\begin{array}{l}\text { t- } \\
\text { count }\end{array}$ & $\begin{array}{l}\text { Descriptio } \\
\text { ns }\end{array}$ & $\begin{array}{l}\text { Standardiz } \\
\text { ed Solution }\end{array}$ & $\begin{array}{l}t- \\
\text { coun } \\
t\end{array}$ & $\begin{array}{l}\text { Descriptio } \\
\text { ns }\end{array}$ \\
\hline Knowledge & Behavior & 0.31 & 1.64 & $\begin{array}{l}\text { Insignifica } \\
\mathrm{nt} \\
\text { Insignifica }\end{array}$ & 1.11 & $\begin{array}{l}4.68 \\
-\end{array}$ & $\begin{array}{l}\text { Significant } \\
\text { Insignifica }\end{array}$ \\
\hline Attitude & Behavior & -0.06 & -0.59 & nt & -0.17 & 1.43 & $\begin{array}{l}\text { nt } \\
\text { Insignifica }\end{array}$ \\
\hline Tool & Behavior & 0.73 & 2.31 & $\begin{array}{l}\text { Significant } \\
\text { Insignifica }\end{array}$ & 0.23 & $\begin{array}{l}1.46 \\
-\end{array}$ & nt \\
\hline Counseling & Behavior & -0.17 & -1.00 & $\mathrm{nt}$ & -0.87 & 3.32 & Significant \\
\hline
\end{tabular}

From the results of hypothesis testing (Table 6), it is obtained that the increase in knowledge related to the control of DHF vectors can improve the behavior of DHF vector control in the Kresek society $(\mathrm{t}$-count $=4.68)$. The availability of tools and materials at homes in Kemayoran area has a positive impact on behavior of DHF vector control and it is significant with t-value $=2.31$. The source of information in the Kresek area has a negative impact on the behavior of the DBD Vector Control in the Kresek Community.

\section{Discussion}

From the hypothesis testing results (Table 6) in Kemayoran data, it is found that the knowledge of DHF vector control has a positive effect on DHF vector control behavior but this effect is not significant with $t$-value $<1.96(\mathrm{t}$ value $=1.64)$. Meanwhile, this effect is significant on Kresek data ( $\mathrm{t}$ value $=4.68$ ). This proves that increasing knowledge related to DHF vector control can improve the DHF vector control behavior in the Kresek community. Good knowledge of various aspects of DHF will produce a significant impact on the prevention and control of DHF. On the contrary, a low level of knowledge supports the spread of dengue which causes vectors and viruses to produce new dengue epidemic areas (10). The knowledge improvement can be done with health education program. A study conducted by Abbasi et al in 2016 concluded that students need special attention in future health education programs. Students with knowledge of the disease will report more often on the use of preventive measures. This situation shows that the education program is the main tool in preventing DHF cases, at least until an effective vaccine is present [11].

The results of hypothesis testing in the data of Kemayoran area (Table 4) showed that the tools and materials at home had a positive effect on DHF vector control behavior and were significant with a t-value $>1.96(\mathrm{t}$-value $=2.31)$. On the contrary, this impact showed no significant effect on the data of Kresek area. Therefore, this proves that the availability of tools and materials at home can improve the behavior of DHF vector control in the Kemayoran community.

In table 4 it can be seen that the source of information has a negative impact on the behavior of the DBD vector control but it is not significant with the t-value $<1.96$. On the contrary, this effect shows significant results on data of Kresek area. Therefore, this proves that the source of 
[3] Depkes RI. Petunjuk Teknis Pemberantasan Sarang Nyamuk Demam Berdarah Dengue (PSN DBD) oleh Juru Pemantau Jentik (Jumantik). Jakarta: Dirjen PP \& PL; 2004.

[4] Schmidt WP, Suzuki M, Thiem VD, White RG, Tsuzuki A, Yoshida LM, et al. Population density, water supply, and the risk of dengue fever in Vietnam: cohort study and spatial analysis. PLoS Med [Internet]. 2011;8:e1001082. Available from: http://www.embase.com/search/results?subaction =viewrecord\&from=export\&id=L560010071\%5 Cnhttp://vb3lk7eb4t.search.serialssolutions.com/? sid=EMBASE\&issn=15491676\&id=doi:\&atitle= Population+density,+water+supply,+and+the+risk +of+dengue+fever+in+Vietnam:+cohort

[5] Vong S, Khieu V, Glass O, Ly S, Duong V, Huy $\mathrm{R}$, et al. Dengue Incidence in Urban and Rural Cambodia: Results from Population-Based Active Fever Surveillance , 2006 - 2008 2010;4(11):2006-8.

[6] Nova Pramestuti dan Anggun Paramita Djati DISTRIBUSI VEKTOR DEMAM BERDARAH DENGUE (DBD) DAERAH PERKOTAAN DAN PERDESAAN DI KABUPATEN BANJARNEGARA. 2013;41(3):163-70.

[7] Kemenkes RI. Kendalikan DBD Dengan PSN 3M Plus. Kemenkes RI. 2016.

[8] Ferdinand A. Structural Equation Modelling dalam Peneltian Manajemen. Semarang: UNDIP; 2006.

[9] Green, L.W. and Kreuter M. Health Promotion Planning: An Educational and Ecological Approach. 3rd editio. New York: McGraw-Hill; 2001.

[10] Kumar JR, Kishore A, Kumar SD, Shamshul A, Govind D, Sangharshila B. Knowledge and Awareness regarding Dengue among the Undergraduate health Science students of Dengue Hit region of Nepal Knowledge and Awareness regarding Dengue among the Undergraduate health Science students of Dengue Hit region of Nepal. 2016;(February).

[11] Abbasi A. iMedPub Journals Dengue Fever: A Statistical Analysis Regarding Awareness about Dengue among University Students in Azad Kashmir Abstract Situation in Pakistan. 2016;1-8.

[12] Rohman AA, Sugihantono A, Pendidikan B, Ilmu K, Masyarakat FK, Diponegoro U. Hubungan Paparan Media Informasi Dengan Pengetahuan Penyakit Demam Berdarah Dengue Pada Ibu-Ibu Di Kelurahan Sambiroto Semarang. 2016;4(April). Barat Kota Manado. J Kedokt Komunitas dan Trop. 2014;II(1):9-13. 
[13] Javed N, Ghazanfar H, Naseem S. Knowledge of Dengue Among Students Exposed to Various Awareness Campaigns in Model Schools of Islamabad : A Cross- Sectional Study. 2018;10(4).

[14] Harapan H, Rajamoorthy Y, Anwar S, Bustamam A, Radiansyah A, Angraini P, et al. Knowledge, attitude, and practice regarding dengue virus infection among inhabitants of Aceh, Indonesia : a cross- sectional study. 2018;1-16.

[15] [15] Boonchutima S, Kachentawa K, Limpavithayakul M, Prachansri A. Longitudinal study of Thai people media exposure, knowledge, and behavior on dengue fever prevention and control. J Infect Public Health [Internet]. 2017;1$6 . \quad$ Available from: http://dx.doi.org/10.1016/j.jiph.2017.01.016 